This is the version of the article accepted for publication in Zeitschrift für arabische Linguistik published by Harrasowitz Verlag: https://www.jstor.org/journal/zeitarabling

Accepted version downloaded from SOAS Research Online: http://eprints.soas.ac.uk/23855/

\title{
On Wilmsen on the development of postverbal negation in dialectal Arabic
}

\author{
Christopher Lucas \\ SOAS, University of London
}

Submitted to Zeitschrift für arabische Linguistik. September 2016.

\section{Introduction}

In a recent article and subsequent monograph, WILMSEN $(2013 a, 2014)$ advances a novel proposal regarding the genesis of dialectal Arabic negative constructions that include a postverbal enclitic $-\check{s}$ morpheme. He argues against two commonly held positions: i) that the $-\check{s}$ morpheme is grammaticalized from šay'thing'; and ii) that the various types of negative construction observed in dialectal Arabic are the result of a crosslinguistically common set of cyclical changes in the expression of negation, known as 'Jespersen's cycle'. Instead, Wilmsen proposes that $-\check{s}$ came to function as a negator through reanalysis of the interrogative particle $\check{s} i$, which does not, according to Wilmsen, derive from šay.

The purpose of the present work is to offer a critique of Wilmsen's proposals, and in so doing to address some broader methodological issues for work on syntactic reconstruction, in particular the role that comparative data from unrelated languages have to play in deciding between competing reconstructions.

The paper is structured as follows. Section 2 provides data on the basic verbal negative constructions that occur in dialectal Arabic. Section 3 outlines the consensus view on the evolution of Arabic negation, as well as Wilmsen's alternative hypothesis. Section 4 discusses Wilmsen's criticisms of the consensus view, while section 5 evaluates Wilmsen's alternative, concluding that the consensus view is better supported by the available evidence. Given this conclusion, section 6 seeks to clarify the actual historical relationship between šay'thing', negative $-\check{s}$ and interrogative ši/-š. Section 7 concludes the paper.

\section{Negation in contemporary dialectal Arabic}

Dialects in which the basic means of negating a verbal predicate involves the enclitic -šmorpheme are spoken in one large contiguous area stretching across coastal North Africa, from Morocco into the southwestern Levant, and separately also in much of Yemen, and possibly parts of Oman. In the vast majority of this area, $-\check{s}$ cannot function as the sole exponent of negation, but forms part of a bipartite negation construction together with a preverbal element $m \bar{a}^{1}{ }^{1}$ as illustrated in (1).

(1)

\begin{tabular}{|c|c|c|c|}
\hline $\begin{array}{ll}\text { ana } & \text { ma-bas’al-ak-ši } \\
\text { I } & \text { NEG-ask.IMPF.1SG-2MSG-NEG }\end{array}$ & $\begin{array}{ll}\text { dilwa'ti } & \text { 'amalt } \\
\text { now } & \text { do.PRF.2MSG }\end{array}$ & $\begin{array}{c}\text { walla } \\
\text { or }\end{array}$ & $\begin{array}{l}\text { ma-'amalt-iš } \\
\text { NEG-do.PRF.2MSG-NEG }\end{array}$ \\
\hline $\begin{array}{l}\text { not asking you now whethe } \\
\text { rene Egyptian Arabic; WOID }\end{array}$ & $\begin{array}{l}\text { you did it or not.' } \\
\text { ICH 2006: 366) }\end{array}$ & & \\
\hline
\end{tabular}

However, in the dialects of a few much smaller, non-contiguous regions within these two large areas, it is also possible for enclitic $-s$ to function as the sole exponent of negation in at least some contexts, as illustrated in (2).

\footnotetext{
${ }^{1}$ The length of the vowel in this element varies from dialect to dialect. I refer to it pandialectally as $m \bar{a}$. Similarly, while šay'thing' is realized in almost all dialects where it is retained as a nominal element as $\check{S} \bar{I}$ or $\breve{s} \bar{e}(y)$, I refer to it pandialectally as šay'
} 
This is the version of the article accepted for publication in Zeitschrift für arabische Linguistik published by Harrasowitz Verlag: https://www.jstor.org/journal/zeitarabling

Accepted version downloaded from SOAS Research Online: http://eprints.soas.ac.uk/23855/

(2) šù lli biddak ìyā bactī-k ìyā bass uskut

what REL want.2MSG 3MSGgive.IMPF.1SG-2MSG 3MSGonly be.silent.IMP.MSG

w-tiḥkì-š

and-speak.IRR.2SG-NEG

'Whatever you want I will give you, just be quiet and don't speak.'

(Hebron Palestinian Arabic; SEEGER 1996: 4)

Purely postverbal negation of this kind has thus far been reported in six separate dialects or dialect areas: i) all of the sedentary dialects of historic Palestine, as well as those of northwestern Jordan, southwestern Syria and southern Lebanon (at least) as far as Baskinta (ABU HAIDAR 1979; BEHNSTEDT 1997: 450-1; PALVA 2004; LUCAS 2010); ii) marginally in Cairene Egyptian (LUCAS 2010); iii) the Upper Egyptian dialect described by KHALAFALLAH (1969); iv) in Maltese, but only in prohibitives (AMBROS 1998: 108); v) the Omani dialect described by REINHARDT (1894), which may however no longer exist, since $-\check{S}(i)$ does not function as a negator in most of Oman today (Domenyk Eades p.c.); vi) perhaps also in the small cluster of dialects of the southern part of the Yemeni Tihama that BEHNSTEDT (1985: 172-3) identifies as negating the existential verb fïwith suffixed -ši alone, though whether this morpheme can act as the sole exponent of negation in other contexts in these dialects is not clear.

Negation of verbal predicates in all other dialects is with preverbal $m \bar{a}$ (or lâa) alone, as illustrated in (3) and (4).

(3) mā žarrab’t la’anno mā kān ma'-i wa’’t NEG try.PRF.1SG because NEG be.PRF.3MSG with-1SG time 'I haven't tried because I haven't had time.' (Damascene Levantine Arabic; COWELL 1964: 383)

(4) kill 'arba' w-ḩamīs w-yim'a mā 'asta日gil-ha every Wednesday and-Thursday and-Friday NEG find.heavy.IMPF.1SG-3FSG 'Every Wednesday, Thursday and Friday - I don't find it too onerous.'

(Kuwaiti Gulf Arabic; BRUSTAD 2000: 284)

\section{Approaches to the evolution of Arabic negation}

No one (as far as I am aware) doubts that the oldest of these three negative constructions is the one composed of just the preverbal negator $m \bar{a}$ (or an alternative preverbal element $l \bar{a}$ ). All the ancient Semitic languages, including Quranic Arabic (5), have exclusively preverbal negation.

(5) mā yahuda'ūna 'illā 'anfusa-hum

NEG deceive.IMPF.3MPL exceptself.PL.ACC-3MPL

'They only deceive themselves.'

(Quran 2:9)

Note also that, in the dialects where bipartite negation is usually obligatory, in the crosslinguistically conservative context of proverbs, negation with preverbal $m \bar{a}$ alone becomes a possibility (6).

(6) illi mayhāf min 'aḷāh hāe minn-u

REL NEG fear.IMPF.3MSG from God fear.IMP.2MSGfrom-3MSG

'Fear him who does not fear God.'

(Cairene Egyptian Arabic; BERGMAN 1996: 241)

The question, then, is how the constructions with $-\check{s}$ were innovated. As noted in section 1 , the general consensus is that negative $-\check{s}$ represents one endpoint in the grammaticalization of šay 'thing'. On this scenario, šay', or some derivative thereof, is used so often as a reinforcing element in negative sentences that it is eventually bleached of all meaning and becomes, together with preverbal $m \bar{a}$, simply 
This is the version of the article accepted for publication in Zeitschrift für arabische Linguistik published by Harrasowitz Verlag: https://www.jstor.org/journal/zeitarabling

Accepted version downloaded from SOAS Research Online: http://eprints.soas.ac.uk/23855/

one element in a bipartite negative construction. Numerous observers, beginning, it seems, with GARDINER (1904), have noticed the parallels between this scenario and the documented evolution of negative constructions in various Romance, Germanic and other languages. The most famous case is that of French, in which the original preverbal negator ne is joined by a grammaticalized form of the noun pas 'step' to form a bipartite negative construction. The parallels between Arabic and French become even more compelling if one assumes, like virtually all those who have commented on the matter, that the Arabic construction with -šalone develops out of the bipartite construction through the omission or phonetic reduction of the preverbal element $m \bar{a}$. This is because a directly analogous process has occurred in colloquial French, where negation today is typically with pas alone.

This crosslinguistically common pattern of renewal and loss of negative elements has been known, since DAHL (1979), as 'Jespersen's cycle', naming it for the Danish linguist Otto Jespersen, who described it as follows (JESPERSEN 1917: 4):

The history of negative expressions in various languages makes us witness the following curious fluctuation: the original negative adverb is first weakened, then found insufficient and therefore strengthened, generally through some additional word, and this in turn may be felt as the negative proper and may then in the course of time be subject to the same development as the original word.

A considerable body of literature has emerged in the past few decades, documenting the occurrence of changes of this sort in both European and non-European languages, and investigating such matters as the most common sources of new negative markers, the speed of the cycle and the extent to which its three basic stages tend to represent discrete phases in the history of a language, and the mechanisms which drive cyclical change of this sort (see WILLIS, LUCAS \& BREITBARTH 2013 for an overview). As such, we have a wealth of comparative data to draw on when we wish to reconstruct the progression of apparently similar developments in languages, such as dialectal Arabic, for which pre-modern documentary evidence is relatively scarce.

With this in mind, we turn to Wilmsen's proposals concerning the Arabic developments. Wilmsen's contention is that the immediate source of negative $-\check{s}$ was the particle $\check{s} i$ (or a reduced version $-s \bar{s}$ ) that can in certain contemporary dialects optionally be added to affirmative interrogative clauses to attenuate the force of the question, in a similar fashion to English by any chance. The unreduced version of this particle, typically coming in clause-final position, is a prominent feature of contemporary Levantine varieties, exemplified by Damascus Arabic in (7). It also occurs in this position in the Libyan dialect described by OWENS (1984), as in (8).

(7) ț'ūmt-i 'əžet mən 'and əl-kawwa ši

suit.PL-1SG come.PRF.3FSG fromat the-ironer $\check{s} i$

'Have my suits come back from the cleaners?'

(Damascus Syrian Arabic; COWELL 1964: 378)

(8) il-ḥawli simīn šì

the-sheep fat $\check{s} i$

'Is the sheep fat?'

(Eastern Libyan Arabic; OWENS 1984: 102)

The same Libyan variety also exhibits the reduced version of this particle $-\check{s}$, which, like the homophonous negative morpheme, is a clitic on the predicate:

(9) šiftū-š miḥammad

see.PRF.2MPL-̌̌ Muhammad

'Have you seen Muhammad?'

(Eastern Libyan Arabic; OWENS 1984: 102) 
This is the version of the article accepted for publication in Zeitschrift für arabische Linguistik published by Harrasowitz Verlag: https://www.jstor.org/journal/zeitarabling

Accepted version downloaded from SOAS Research Online: http://eprints.soas.ac.uk/23855/

Despite the homophony, this reduced version of the particle, whose present-day distribution appears largely restricted to the dialects of eastern North Africa (Tunisia, Libya, Malta, Egypt), is clearly not the same item as negative $-\check{s}$. This is can be seen from the example in (10) where it is clear from the context that the $-\check{s}$ morpheme cannot be expressing negation.

(10) bēt abū-ya huwwa fēn walla akun-ši $\check{s}^{i}$ glițti ${ }^{i}$ fi š-šāric

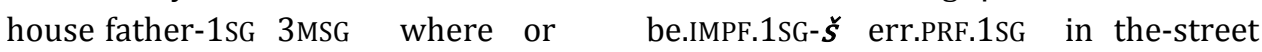
'Where's my father's house? Or have I got the wrong street?' (Cairene Egyptian Arabic; WOIDICH 2006: 358)

While Wilmsen is very clear on his view of the etymology of negative $-\check{s}$ ("[r] eanalysis of the polar interrogative $\check{s} i$ is what produced the negator $\breve{s}, 2014: 209$ ), it can be hard to pin down precisely how he sees this reanalysis having taken place. Consider first of all his claim (2013a: 26-7) that "Arabic dialects negating without a pre-posed mā with forms like fǐs and biddīš and tistahīš have not lost the prepositioned negator in a third stage of Jespersen's cycle, for, such forms have been in place as long as an enclitic -š has been used in interrogation and negation". ${ }^{2}$ This must surely be taken as amounting to the claim that $\check{s}(i)$ was reanalysed as a negator in sentences not containing $m \bar{a}$, i.e. affirmative (interrogative) sentences. Although he does not state this clearly, it seems that Wilmsen has in mind specifically rhetorical questions analogous to (11) as the kind of context in which a speaker could intend an affirmative polar question, while the addressee, reanalysing, parses the utterance as negative.

$\begin{array}{clllll}\text { (11) 'sm-u } & \text { 'lyy } & \text { w-hu } & \text { ’̌s } & \text { yğț } & \text { riğlayy } \\ \text { name-3ms } & \text { on.1s } & \text { and-he } & -\check{s} & \text { cover.IMPF.3MS } & \text { leg.PL.1S }\end{array}$

WILMSEN'S (2013a: 17) suggested interpretation: 'His name is on me, but does it cover my legs?' Potential innovative interpretation: 'His name is on me, but it does not cover my legs.'

(Andalusi Arabic; AL-'AHWĀNī 1962: 314, cited by WILMSEN 2013a: 14)

On this scenario, the chronological sequence of possible negative constructions would therefore have been PREVERBAL $>$ POSTVERBAL > BIPARTITE, rather than PREVERBAL > BIPARTITE > POSTVERBAL, as assumed in the traditional Jespersen-type scenario outlined above.

Various statements in WILMSEN (2014) point in a different direction, however. For example, he says (2014: 115): "it remains only to hypothesize that the negative quality of $-\check{s}$ came about as a reanalysis of the negative response to polar questions formed with any part of speech, requiring an answer 'yes' or 'no', it being negated with $m a \bar{a}$ with an associated cliticized $\check{s} i$, such that the $-s ̌$ began to lose its interrogative quality" (emphasis added). This confusing claim requires some picking apart. Here it seems Wilmsen is suggesting that it was not polar questions themselves (containing $\check{s}_{i}$ ) that were reanalysed as negative. Instead, he is suggesting that the interlocutor's response to such questions is the locus of reanalysis: specifically, responses that are negated with $m \bar{a}$, but which also contain $\check{s} i$. It is apparently this hypothesized development that the illustrations reproduced in (12) are supposed to represent.

(12) a.From WILMSEN (2014: 209):

Negator: 'is?' > 'not is'

(h(uw)(iy)a)ši? $\rightarrow$ mā (h(uw)(iy)a)ši!

'Is he/she/it?' $\rightarrow$ 'He/she/it is not'

b. From WILMSEN (2013b: 33):

huwā-š? $\rightarrow$ Lā. mā huwā-š

2 This passage is repeated with added hedges and a tweaked final clause in WILMSEN (2014: 117):

"Arabic varieties negating without a pre-posed mā with forms like fǐš and biddī̌s and tistaḥiš have not necessarily lost the pre-positioned negator in a third stage of Jespersen's Cycle, for such forms may well have been in the language throughout the entire time that the process of reanalysing interrogatives as negators has been taking place." 
This is the version of the article accepted for publication in Zeitschrift für arabische Linguistik published by Harrasowitz Verlag: https://www.jstor.org/journal/zeitarabling

Accepted version downloaded from SOAS Research Online: http://eprints.soas.ac.uk/23855/

he-it.is? no not he-is

'Is he?' $\quad \rightarrow \quad$ 'No. He isn't'

An important question to ask regarding this scenario is: why would these negative responses, which are of course declarative, not interrogative, contain interrogative $\check{s} i$ ? There seems to be no reason for thinking they should, and Wilmsen does not provide one. As such, it is unlikely that this particular hypothesis is on the right track.

A third hypothesis hinted at by Wilmsen is that it is ši in the function of an indefinite determiner 'some, any' that was reanalysed as a negator. This is more plausible, and was, in fact, proposed by DAVIES (1981) (though see LUCAS 2010: 183, fn.17 and DIEM 2014: 9 for problems with this hypothesis). WILMSEN (2014: 57) suggests that "ši begin[s] to acquire negative connotations when occurring as part of a longer construction, often likely remaining an interrogative, with the pseudo-verb governing a true object: * mā 'andak ši + [indefinite noun] 'you don't/don't you have any [entity]' and *mā fi ši + [indefinite noun] 'there is/is there not some [entity]'” (emphasis added). While this scenario is certainly plausible, it is hard to square with Wilmsen's basic contentions that a) the immediate ancestor of negative $-\check{s}$ is specifically interrogative $\check{s} i$, and b) purely postverbal negation did not emerge through omission of preverbal mā in a third stage of Jespersen's cycle. Concerning (a), in the above quote Wilmsen himself indicates that $\check{s} i$ is not necessarily interrogative on this scenario, and he offers no evidence to support his claim that the construction in question "often likely remain[ed] an interrogative". Concerning (b), this scenario in fact entails a classic three-stage Jespersen-style development in the expression of negation: PREVERBAL>BIPARTITE>POSTVERBAL. The only important respect in which the scenario diverges from the mainstream view of the evolution of Arabic negation concerns WILMSEN'S (2014) wider proposals about the ultimate origin of the various types of $\check{s}(i)$ morphemes. As noted above, Wilmsen rejects the usual derivation from šay'thing', and instead proposes that grammatical $\check{s}(i)$ derives ultimately from the ProtoSemitic $3^{\text {rd }}$ person pronouns formed with $s^{1}(*[s])$, which, following traditional practice, Wilmsen transcribes as $\check{S}$. As explained in detail by AL-JALLAD (2015; see also the reviews of WILMSEN 2014 by PAT-EL 2016 and SOUAG 2016), this etymology is untenable, since Arabic $\check{s}$ corresponds to Proto-Semitic $s^{2}(*[1])$, not $s^{1}$. For more on the generally accepted etymology $-\check{s}<\check{s} a y$, see section 5 .

There is thus no single, coherent proposal that Wilmsen offers for precisely how the development he envisages - from interrogative $\check{s} i$ to negative $-\check{s}$ - might have proceeded. Despite this, we can nevertheless allow that the development itself is plausible in principle. The same can perhaps also be said for Wilmsen's proposed dating and siting of the change. LUCAS \& LASH (2010) argue that negation with $-\check{S}$ most likely arose in Egypt some time between the $8^{\text {th }}$ and $11^{\text {th }}$ centuries $C E$, and then diffused through neighbouring dialects westwards across North Africa and eastwards into the southwestern Levant (positing a separate, undated development for the presence of $-\check{s}$ negation in Yemen). By contrast, WILMSEN (2014: 212) suggests that negation with $\check{S}(i)$ is "likely to have been present [throughout the western Arabian Peninsula and Fertile Crescent] before the 7th century AD, perhaps for as long as a millennium and a half, but certainly present around the time that Arabic-speaking Muslims arrived". The fact that negation with $-\check{s}$ in the present day is absent from the vast majority of the Fertile Crescent WILMSEN (2014: 146) puts down to "later waves of bedouinization", suggesting (2014: 212) that "Arabic speakers whose dialects retained the reflexes of ši used in negation could have lost that feature in less than a generation" once the Islamic conquests caused them to come into contact with Peninsular Arabs whose dialects lacked this feature.

If we accept that Wilmsen's proposals for the etymology and dating of negative $-\check{s}$ are plausible in principle, the question then is whether they are preferable to the existing reconstruction, and, more broadly, what kind of criteria we should use to distinguish between competing hypotheses of this sort. We deal with this question in the next two sections: section 4 addresses Wilmsen's criticisms of the traditional view, while section 5 outlines some of the problems with Wilmsen's hypothesis. 
This is the version of the article accepted for publication in Zeitschrift für arabische Linguistik published by Harrasowitz Verlag: https://www.jstor.org/journal/zeitarabling

Accepted version downloaded from SOAS Research Online: http://eprints.soas.ac.uk/23855/

\section{Wilmsen's criticisms of the Jespersen-type reconstruction}

It seems that Wilmsen has three main objections to the Jespersen-type reconstruction of the history of Arabic negation. First, that the mechanisms by which šay"(any)thing' could come to be grammaticalized as a negator have never been made clear. Second, that this scenario depends on erroneous assumptions about the relationship between Classical Arabic and the contemporary dialects. Third, that comparisons between the Arabic developments and the history of negation in French are unhelpful. Let us consider each of these points in turn.

WILMSEN (2013a: 10, 2014: 45) claims that the assumptions about the grammaticalization of say' '(any)thing' "are never supported by linguistically defensible mechanisms". Given this claim, it is surprising that Wilmsen chooses to critique ESSEESY'S (2010: 65-6) very brief presentation of this reconstruction, when all concerned are in agreement that this is "highly schematic" (WILMSEN 2013a: 9, 2014: 44) and in no way constitutes the focus of that work or of ESSEESY (2009), where the same reconstruction is also briefly mentioned. By contrast, I discussed various possibilities for these developments in some detail in LUCAS (2007: 416-23), a work that Wilmsen cites several times in other contexts. There I argued that one plausible scenario for the grammaticalization of šay'as a negator is via an intermediate stage as an adverb with a negative-polarity-item (NPI) distribution, that is, like English at all, restricted to negative, conditional and interrogative contexts, and most frequent in negative contexts. This is, of course, not so dissimilar to Wilmsen's proposal for the immediate origin of negative $-\check{s}$ (see section 6 for further discussion). However, in LUCAS (2007) I go on to argue that a preferable reconstruction is one which sees $\check{s}^{\prime} y^{\prime}$ (or a reduced form $\check{s}$ ) in the function of an indefinite pronoun 'anything' as the item that was reanalysed as a negator, ${ }^{3}$ in view of pseudo-verb structures such as (13), in which $-\check{s}$ appears to function both as negator and indefinite pronoun.

(13) wi ma-mªnā-š yikammil taman id-dawa and have.1PL-NEG+anything complete.IMPF.IRR.3MSG price the-medicine 'and we don't have anything that could make up the cost of the medicine' (Cairene Egyptian Arabic; WOIDICH 1968: 40)

Whether this reconstruction should be taken as definitive is naturally open to debate, but it is odd that Wilmsen chooses not to engage with it at all, ${ }^{4}$ since it directly addresses criticisms he makes (2013a: 10,

\footnotetext{
${ }^{3}$ Note that šay'can safely be assumed to have already had an indefinite-pronoun function in pre-diaspora vernacular Arabic, at least in the context of negation, since there are a number of examples of this kind in the Quran, e.g.:
} and-NEG associate.JUSS.2MPL with-3MSG 'and do not associate anything with Him' šay’an (Quran 4:36)

${ }^{4}$ The decision is perhaps explained by WILMSEN'S (2013a: 8) claims that "[b]ecause LUCAS (2007) and LUCAS \& LASH (2010) pin their arguments upon an erroneous assessment of the nature of Andalusi Arabic [reference omitted - CL], their curious hypotheses may safely be disregarded" and that "LUCAS (2007 \& 2010) and LUCAS \& LASH (2010) cast about for an explanation of the negation technique, arriving at several novel and mutually contradictory conclusions about its origins". While I am grateful to Wilmsen for indirectly drawing my attention, through the first claim, to a minor error in LUCAS (2007), repeated in LUCAS (2009) and LUCAS \& LASH (2010), these two assertions of his are, in fact, baseless. The error in question is my claim that "one of the commonest negative constructions" (LUCAS 2007: 411) in Andalusi Arabic is a form iš. This is not quite right, and was probably the result of my confusing $i \check{s}$ with another nonstandard Andalusi negator lis, concerning which CORRIENTE (1977: 144) says that it, together with other reflexes of the Classical Arabic negative verb laysa, "seemed to dominate the negative transformations of Sp[anish] Ar[abic], except in its latest period". CORRIENTE (1977: 145) says of išonly that it is one of the attested negators of Andalusi Arabic and that it is "common" in one text and "standard" in another, rather than being common throughout all texts in that dialect. But to suggest that 
This is the version of the article accepted for publication in Zeitschrift für arabische Linguistik published by Harrasowitz Verlag: https://www.jstor.org/journal/zeitarabling

Accepted version downloaded from SOAS Research Online: http://eprints.soas.ac.uk/23855/

2014: 45) of Esseesy's presentation of the Jespersen-type approach and the valency-changing consequences of šay"anything' being reanalysed as a non-argument negator. Regarding this issue Wilmsen makes the following objection: if we suppose that šay'anything' is reanalysed as a nonargument negator when functioning as the object of some verb, then this reanalysis must also change the verb from transitive to intransitive in that context; but in this case, WILMSEN (2013a: 10, 2014: 45) observes, there is then "no motivation" for later also negating unambiguously transitive verbs with $\check{s}\left(a y^{\prime}\right)$. Here it seems that Wilmsen is failing to distinguish between reanalysis and 'extension' (HARRIS \& CAMPBELL 1995) or 'actualization': "the gradual mapping out [in a wider range of grammatical contexts CL] of the consequences" of a reanalysis (TIMBERLAKE 1977: 141). It is a basic observation of syntactic change that reanalyses tend to happen first in a particular 'bridging context' (CLARK 1975, HEINE 2002), and that the new structures often take many generations to spread to a wider set of contexts (see, e.g., KROCH 1989 on the gradual spread of $d o$-support in Early Modern English, and LUCAS 2010 for some suggestions for what drives extension/actualization in general).

While we do not have any documentary evidence for this kind of gradual spread with negative $\check{s}\left(a y^{\prime}\right)$ in Arabic, directly equivalent developments can be observed in other languages which have undergone, or are in the process of undergoing, Jespersen's cycle. For example, in the Romance language Venetan there is an apparently recently grammaticalized negative strengthener gnente 'at all' that co-occurs with the preverbal negator no (POLETTO 2008: 72-74). At the same time, an identical form (gnente) continues its original function as a negative indefinite pronoun occurring in a wide range of contexts. Adverbial gnente, on the other hand, occurs principally with a restricted class of intransitive verbs, as in (14), and is only compatible with a direct object when this is part of an explicit contrast, as in (15).

(14) No-l dorme gnente
NEG-3MSG sleep.PRES.3SG gnente
'He doesn't sleep at all.'
(Venetan; POLETTO 2008: 72)
(15) a.*No-l leze gnente i libri
NEG-3MSG read.PRES.3sG gnente the books
Intended meaning: 'He doesn't read books at all.'
b. No-l leze gnente libri, solo giornai
NEG-3MSG read.PRES.3sG gnente books only newspapers
'He doesn't read books at all, only newspapers.'
(Venetan; POLETTO 2008: 73)

By contrast, in related varieties such as Piedmontese, where the cognate element nen is a fully grammaticalized negator that can function as the sole expression of negation in a clause, there is no longer any restriction according to verb type (ZANUTTINI 1997: 67).

This comparative evidence adds weight to what should anyway be the default assumption, given the well-established concept of actualization: if it was indeed šay'as an indefinite pronoun 'anything' that was first reanalysed as a negator, then we should expect that its unrestricted present-day distribution would only have come about gradually, and that it was restricted initially just to intransitive verbs. So it is

this error has significant consequences for the principal arguments of LUCAS (2007) and the other papers is simply wrong, as readers of those papers may verify for themselves. The second claim - that the three papers arrive at mutually contradictory conclusions about the origins of negative $-\check{s}$-is similarly misleading. The only point on which LUCAS \& LASH (2010) contradict LUCAS (2007) is that the latter paper assumed, in keeping with all previous literature on the topic, that Jespersen's cycle in Arabic was purely internally caused, whereas LUCAS \& LASH (2010) argue that it was contact-induced, citing evidence from Coptic and Modern South Arabian languages that I was not aware of when I wrote the earlier paper. In each case the assumed origin of negative $-\check{s}$ is identical: šay'thing'. As for LUCAS (2010), this paper does not deal with the origin of negative $-\check{s}$ at all, but rather the innovation of negation with $-\check{s}$ alone in Palestinian and Cairene Arabic (see fn.6). 
This is the version of the article accepted for publication in Zeitschrift für arabische Linguistik published by Harrasowitz Verlag: https://www.jstor.org/journal/zeitarabling

Accepted version downloaded from SOAS Research Online: http://eprints.soas.ac.uk/23855/

wrong to suggest that there are no well-understood mechanisms by which šay'(any)thing' could have come to function as an unrestricted negator.

Wilmsen's second objection to Jespersen-type reconstructions of the Arabic facts is that "they seem to have been adopted whole from medieval linguistic traditions about the Arabic dialects arising as corruptions of [Classical Arabic]" (WILMSEN 2013a: 10, 2014: 45). It is hard to see much justification for this claim at all, beyond the fact that ESSEESY (2010: 65) includes a nominative-inflected form of šay'šay'un - as part of his schematization of the initial stage of Jespersen's cycle in Arabic. WILMSEN (2013: 8, 2014: 50) also cites OBLER'S (1990: 136) perfectly reasonable statement that "Classical Arabic, whatever its status, can in any case be taken as representative of a form of Arabic earlier than that of the modern dialects", wrongly suggesting that taking such a view entails the belief that "the Arabic dialects arose after the Arab diaspora". Believing, as most linguists working on Arabic today do, that the Arabic dialects cannot be said to descend from the Arabic variety of the Quran and pre-Islamic poetry should not blind us to the truism that early vernacular Arabic will have been in many respects more similar to Classical Arabic than the present-day dialects are (cf. DIEM 2014: 13). And this is especially likely to be true of features such as exclusively preverbal negation, concerning which Classical Arabic, other ancient Semitic languages, and contemporary Bedouin dialects of the Arabian Peninsula are all in agreement. In the absence of compelling evidence to the contrary, therefore, it is sensible to treat the negation system of Classical Arabic as being basically similar to that of pre-Islamic vernacular Arabic. It should go without saying that this does not entail the most likely incorrect view that pre-Islamic vernacular Arabic was identical to Classical Arabic.

Finally, Wilmsen is scathing about the comparisons between the various Arabic negative constructions and those of French, which he sees as being "dutifully mentioned by all" (2013a: 26, 2014: 117) who discuss the Arabic developments. His position seems to be that, at least in this case, comparative data from apparently similar developments in unrelated languages are actively misleading. This is an important issue, and it merits some discussion.

On the one hand, there is no doubt that linguists need to guard against bringing analytical biases derived from well-studied languages to bear on less well-studied languages (cf., e.g., VAN VALIN'S 2010: 704 criticism of Anglo-centric syntactic frameworks in which the notion of 'subject' is taken to be universal). HASPELMATH (2007: 125) is surely right that "[i]nstead of fitting observed phenomena into the mould of currently popular categories, the linguist's job should be to describe the phenomena in as much detail as possible, using as few presuppositions as possible". At the same time, no one can reasonably deny that syntactic reconstructions should, in general, be informed by familiarity with changes from the same domain in other languages. DEUTSCHER (2006: 464) notes that, as a result of intensive work on grammaticalization in hundreds of languages over the past few decades:

A picture of overwhelming unidirectionality has emerged, where language after language goes down similar paths of change, from concrete lexical elements to abstract grammatical markers, and often from the same lexical sources to the same grammatical elements. It is obvious why such insights are important for reconstruction, whether in Semitic or in any other language family. Just as phonological reconstruction requires an awareness of what sound changes are likely (e.g. $p>f$ is very likely, $f>p$ exceedingly unlikely), so does the unidirectionality of many 'grammaticalization' changes provide a framework for reconstructing morphology and syntax.

The question, then, is how to negotiate the potentially conflicting requirements of looking at each change in each language with fresh eyes on the one hand, and ensuring on the other that our reconstructions are informed by an understanding of the types of changes that comparative work should lead us to expect. My own answer to this question would be that all possible language-internal data must be considered when developing reconstructive hypotheses - spotting parallels with the histories of other languages is useless if it is based on a superficial inspection of the language under investigation - but whenever there is a choice to be made between two possible hypotheses or interpretations of data, a choice which cannot be 
This is the version of the article accepted for publication in Zeitschrift für arabische Linguistik published by Harrasowitz Verlag: https://www.jstor.org/journal/zeitarabling

Accepted version downloaded from SOAS Research Online: http://eprints.soas.ac.uk/23855/

decided purely by internal considerations, we ought to favour the hypothesis or interpretation which conforms most closely to patterns of change that have been observed in other languages.

\section{Problems with Wilmsen's proposals}

While the final stage of Wilmsen's proposed etymology of negative $-\check{s}$ - that it derives from interrogative $\check{s i}$ - seems plausible, it is worth noting that there do not appear to be any documented cases of a negator deriving from a particle marking polar interrogatives (see, e.g., DEVOS \& VAN DER AUWERA 2013: 2323). ${ }^{5}$ Given the preceding discussion, however, a more important point is that Wilmsen's proposals are not favoured by the Arabic-internal facts either. Two pieces of evidence are especially relevant here: i) the existence of dialects in which the postverbal negator has an allomorph that is unequivocally a reflex of šay; ii) the (restricted) geographical distribution of both the bipartite $(m \bar{a} . . .-\check{s})$ and purely postverbal $(-\check{s})$ constructions in present-day dialects. We deal with both of these points in turn in the following.

As noted in section 3 , Wilmsen's proposal that the Proto-Semitic $s^{1}$ pronouns are the ultimate source of negative $-\check{s}$ displays a disregard for, or confusion about, the details of sound correspondences in Semitic (Al-Jallad 2015). A similar attitude can be discerned in Wilmsen's (2014: 58, fn. 20) suggestion that we need "not concern ourselves with the vowel differences between $\check{s} a y$ ', šay, $\check{s} \bar{e}$, $\breve{s} \bar{l}$, and $\breve{s} i$, or with the presence of the glottal stop in two of them". It should go without saying that these differences represent crucial pieces of evidence for reconstructing the chronological relationships between these various reflexes of what everyone agrees is ultimately the same basic item. For example, it is only by ignoring this phonological evidence that Wilmsen can suggest that šay'thing' in fact derives from the indefinite determiner use of $\check{s} i$, rather than vice versa. The fact is, historical monophthongization and loss of final glottal stop are well-attested features of most Arabic dialects, whereas the reverse processes are virtually unattested. As such, the existence of dialects in which there is a non-monophthongized alternative form of the postverbal negator strongly points towards such forms being original. For example, HEATH (2002: 212) records ma...-šay as a rare variant of ma...-š in two Moroccan dialects: Zagora in the south, about $400 \mathrm{~km}$ east of Agadir, and Taounate in the north, about 70km northeast of Fes. Heath (2002: 212) also notes that šay"occurs more widely in M[uslim] dialects [of Morocco - CL] as an emphatic version of ma...$\breve{s}^{\prime \prime}$ (see also Caubet 1993: 68). Similarly, KHALAFALLAH (1969: 100-2) reports šey as being the basic negative morpheme in the Qinā-governorate dialect of Egyptian Arabic that he describes. To judge from his examples, -šey has an allomorph -ši in this variety, -šey occurring utterance-finally, -ši elsewhere. It is hard to think of a plausible interpretation of this data other than that these non-monophthongized forms are relics, and the more widespread $-\check{s}$ (i) forms are derived from them, having been subject to the kind of phonetic reduction typically associated with grammaticalization. There is thus no reason to doubt that the ultimate origin of $-s$ negation is a form šay?

Turning to the geographical evidence, the problem here is that neither the bipartite nor the purely postverbal constructions have the kind of distribution in present-day dialects that we would expect if Wilmsen were correct that the purely postverbal construction is at least as old as the bipartite construction and that either or both were "present [throughout the western Arabian Peninsula and Fertile Crescent] before the 7th century AD, perhaps for as long as a millennium and a half" (2014: 212).

As noted in section 2 , the bipartite $m \bar{a} . . .-\check{s}$ construction is the default for negating verbal predicates in the sedentary dialects spoken all across coastal North Africa (including Maltese) and into the Levant, and also in much of Yemen. By contrast, negation with $-s$ alone is attested only sporadically within this large region, having been reported in six separate areas: Palestine and surrounding parts of the Levant, marginally in Cairo (and presumably also much of the Delta), Upper Egypt, Malta, part of the southern Yemeni Tihama, and the late nineteenth-century Omani dialect of the Hajar mountains and Zanzibar (REINHARDT 1894). If, as WILMSEN (2013a: 26-7) claims, "Arabic dialects negating without a pre-posed

\footnotetext{
${ }^{5}$ Though DRYER (2009) does tentatively propose that the origin of many of the clause-final negators of central African languages could be reanalysis of clause-final question particles. And interrogative pronouns, as opposed to particles marking polar questions, do seem to be an attested source of negators (see LUCAS 2013: 402).
} 
This is the version of the article accepted for publication in Zeitschrift für arabische Linguistik published by Harrasowitz Verlag: https://www.jstor.org/journal/zeitarabling

Accepted version downloaded from SOAS Research Online: http://eprints.soas.ac.uk/23855/

$m \bar{a}[\ldots]$ have not lost the pre-positioned negator [...], for, such forms have been in place as long as an enclitic -š has been used in interrogation and negation", then why is this purely postverbal negative construction so rarely attested as a possibility today? Wilmsen would presumably have to answer that it has been lost in all the other dialects which retain the bipartite construction. But how might this have happened? While the presence of purely postverbal negation (alongside bipartite negation) throughout Palestine and neighbouring areas of the Levant is plausibly explained as resulting from innovation of this construction (via omission of $m \vec{a}$ ) in one sub-dialect and its subsequent diffusion throughout the rest of that region, it is not plausible to argue that an innovation resulting in the absence of this construction (with no new construction gained) could diffuse in the same way. Since there is also no possibility of arguing that all the dialects without the purely postverbal construction form a genetic subgroup, Wilmsen's account requires him to posit a huge number of independent parallel losses of purely postverbal negation in those dialects. While it might at first glance seem unparsimonious to posit six independent innovations of $m \bar{a}$-dropping in the dialects listed above, it is clearly extremely unparsimonious to posit countless independent parallel losses of the purely postverbal construction. ${ }^{6}$

Then there is the fact both the bipartite and the purely postverbal constructions are absent in the present-day dialects of the whole of Iraq and most of Syria, despite this being the region in which Wilmsen believes the construction was once widespread. As noted above, WILMSEN (2014) believes that negation with $-\check{s}(i)$ was lost in these regions after the Islamic conquests as a result of contact with supposedly prestigious Peninsular dialects negating with preverbal māalone. While here we at least have a mechanism that is plausible in principle, it remains the case that positing the innovation and subsequent loss of a construction in a set of dialects is less parsimonious than assuming the dialects in question never had the construction at all. The less parsimonious hypothesis should be rejected unless we have strong evidence to support it. Wilmsen offers two types of evidence on this score, but neither stand up to scrutiny.

The first line of argument that Wilmsen pursues focuses on the presence in Maltese, Cypriot Maronite Arabic and Central Asian Arabic of items derived from qatt ${ }^{\prime}(n)$ ever, (not) at all' plus a suffixed $\check{s}$. These are Maltese qattx 'ever', 7 Cypriot kitš 'nothing' and Central Asian qattišs'nothing'. WILMSEN (2014: 149) views the $-s$ in these items as the familiar negative morpheme, seeing in it a "remnant of an earlier negation pattern, complete with suffixed $-s^{\prime \prime}$, which has otherwise been lost in Cypriot and Central Asian. In the case of these latter two dialects this analysis is untenable, given the existence of dialects in which the equivalent expression is transparently composed of two morphemes *qatt 'no' and *šay'thing', for example qatt šìya 'nothing' in the Kinderib dialect of southeastern Turkey (JASTROW 2005: 115; cf. SOUAG 2009: 62; cf. also qətt-ahhad 'no one' in the same dialect). Maltese qattx should be seen as a separate development of the same original items, though the suffix cannot be derived from negative $-\check{s}$ here either, since qattx, meaning 'ever', is non-negative and does not occur in negative sentences (BORG 2004: 389; the meaning 'never' in negative sentences is rendered by qattwithout suffixed $-x$. See section 6 for more on non-negative $-x$ in Maltese). There is thus no good linguistic evidence that negation with $-\check{s}$ was formerly present in dialects of the Fertile Crescent that lack it today.

Wilmsen's second line of argument relates to the present-day distribution within Syria of dialects which at least optionally feature the bipartite $(m \bar{a} . . .-\check{s})$ construction. Referring to Figure 1 (reproduced from BEHNSTEDT \& WOIDICH 2005: 101), WILMSEN (2014: 213) suggests that "the dialect islands in the

\footnotetext{
${ }^{6}$ Also relevant here is the fact that, at least in Cairene and Palestinian, there are clear restrictions on the grammatical contexts in which purely postverbal negation can appear, and these are very different in each of these two dialects - further evidence that the presence of this construction in both should be seen as the result of two independent developments. This issue is discussed in detail in LUCAS (2010). Regarding the process of data collection for Palestinian in that work, WILMSEN (2014: 102) suggests that "its technique and sample size limit its reliability". Readers of LUCAS (2010) may judge that issue for themselves, but note that the findings presented there are fully consistent with those of other scholars who have described the distribution of negation in the dialects of Palestine and neighbouring areas of the Levant (e.g. OBLER 1975: 101, 105; SHAHIN 2000: 37; SEEGER 2013: 148-9, p.c.; HERIN 2014).

${ }^{7}$ Maltese $<x>$ represents IPA $/ \int /$, otherwise transcribed here as $<\breve{s}>$.
} 
This is the version of the article accepted for publication in Zeitschrift für arabische Linguistik published by Harrasowitz Verlag: https://www.jstor.org/journal/zeitarabling

Accepted version downloaded from SOAS Research Online: http://eprints.soas.ac.uk/23855/

Syrian steppe, where negation with $-\check{s}$ is optional, look to be precisely what would be expected in a geography where a major dialect change had taken place [i.e. widespread loss of negation with $-\check{s}-\mathrm{CL}$ ]: remote island holdouts that the change had passed over". This line of argument backfires, however, if we consider the dialect geography of the Syrian steppe in more detail. The information given in Figure 1 is a simplified version of that provided by BEHNSTEDT (1997: 450-1) in his Sprachatlas von Syrien. In the latter work we see that, while the bipartite construction is at least optional in the oasis towns of ilQaritēn, Palmyra and Soukhne, in many of the smaller villages surrounding these towns it is absent. It has long been known that innovations will often 'jump' from one urban settlement to the next faster than they spread through the villages in between (e.g. TRUDGILL 1974). The reasons for this can be complex, but a key factor is the fact that population size and density is typically at least as important a determinant of contact between settlements as mere proximity. Against this background, it seems unlikely that these oasis towns should have been conservative with regard to developments in the expression of negation while the more remote surrounding villages have been innovative. Instead, the distribution of $-\check{s}$ negation in Syria is fully consistent with its being an innovation that has spread from the southwest, and not an ancient feature whose loss has gradually diffused from the east. ${ }^{8}$

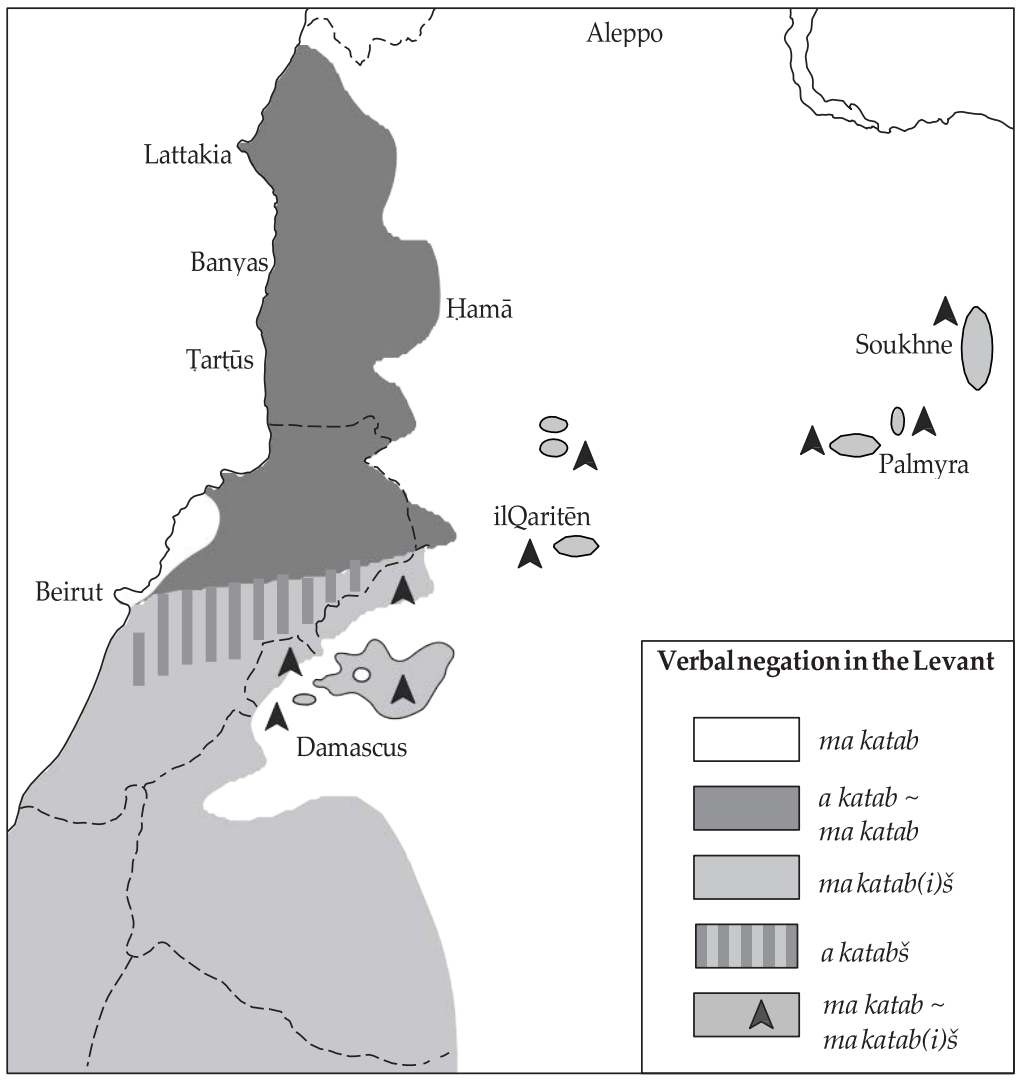

Figure 1. Distribution of negative constructions in the northwestern Levant Source: BEHNSTEDT \& WOIDICH 2005: 101 (via WILMSEN 2014: 153)

\footnotetext{
${ }^{8}$ Mention should be made here of the non-contiguous distribution of the construction in the dialects north of Damascus. That Damascus itself and the area immediately surrounding it have resisted adoption of this external feature can be attributed to the considerable local prestige of this dialect (the same argument applying to the dialect of Beirut). The thin band of $\check{s}$-less dialects running parallel to the border with Lebanon, on the other hand, corresponds closely to the area of the Qalamoun mountains - a region where linguistic conservatism is to be expected.
} 
This is the version of the article accepted for publication in Zeitschrift für arabische Linguistik published by Harrasowitz Verlag: https://www.jstor.org/journal/zeitarabling

Accepted version downloaded from SOAS Research Online: http://eprints.soas.ac.uk/23855/

In summary, the Arabic-internal linguistic and geographical facts do not support Wilmsen's novel reconstruction of negative $-\check{s}$. As such, the conventional Jespersen-type reconstruction remains the most plausible account that has yet been offered of the emergence of this morpheme. In the following section I offer some more detailed suggestions for what this account entails, and how we should understand the diachronic relationship between negative $-s ̌$ and interrogative $\check{s} i /-\check{s}$.

\section{How are šay"(any)thing', negative -šand interrogative ši/-šrelated?}

In order to understand more clearly how šay"(any)thing', negative -šand interrogative šil-šare related, we first need to clarify the true status of the non-negative $-\check{s}$ morpheme, illustrated in (9) and (10), that Wilmsen sees as being restricted to interrogative contexts. There is no good reason to doubt that this morpheme, like the homophonous negative morpheme, derives from šay', and is a reduced form of the usually clause-final particle $\check{s} \grave{l} / s \check{i}$, illustrated in (7)-(8). The fact that the unreduced version of this morpheme may, in at least some dialects, also occur directly after the predicate, as in (16), presents an obvious route via which it could have become a verbal enclitic.

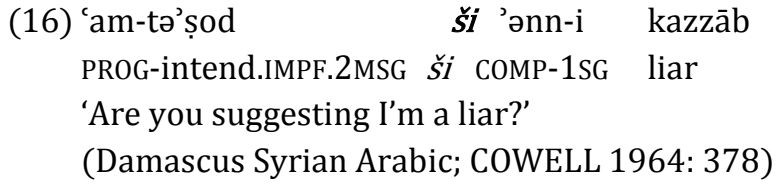

Grammars of dialects that feature either the free or clitic form of this item (or both) all seem to report them as being restricted to polar questions (either main-clause or embedded), with some authors (e.g. WOIDICH 2006: 306) adding that the effect is to make the question more tentative than it would otherwise be, as with English at all, in any way, by any chance. While it is perfectly plausible that a specialized question particle could grammaticalize from an indefinite pronoun such as šay', evidence from the grammaticalization of indefinite pronouns as adverbs in other languages (e.g. Welsh; WILLIS 2013: 245), leads us to expect that there will have been an intermediate stage in which a generalizing particle of this kind had an NPI distribution, occurring also in negative and conditional contexts. There is, in fact, some evidence that this was the case. We saw above that in a number of Moroccan dialects emphatic negation may be expressed with ma...-šay rather than the more normal ma...-̌̌. Similarly, WATSON (1993: 261) says of Șan'ānī Yemeni Arabic that "where šs̆is used in place of -̌̌s, it often emphasises the negative element", giving the following example:

\begin{tabular}{|c|c|c|}
\hline (17) ba'dma & tzawwajt & ḩarağt \\
\hline after & marry.PRF.1SG & leave.PRF.1SG ŠI \\
\hline
\end{tabular}

Deciding whether $\check{s} \grave{l} /$ šayin constructions such as this should synchronically be considered part of a bipartite negative construction or whether it is instead merely a non-negative NPI adverb like English at all or one bit is a complex and controversial matter, ${ }^{9}$ and one that need not concern us here. More instructive is that, at least in Maltese, non-negative $-\check{s}$ (orthographically $-x$ ) occurs not only in root interrogative clauses as in (18) and embedded interrogative clauses introduced by the conditional particle jekk 'if, whether' as in (19), but also occasionally in true conditional clauses, as in (20).

\footnotetext{
${ }^{9}$ As such, WILMSEN (2013: 12-3, 2014: 68-9) is too hasty in declaring the three written examples he is able to find of Andalusi negative constructions containing šĭ to be "unequivocal" evidence of bipartite negation in that variety.
} 
This is the version of the article accepted for publication in Zeitschrift für arabische Linguistik published by Harrasowitz Verlag: https://www.jstor.org/journal/zeitarabling

Accepted version downloaded from SOAS Research Online: http://eprints.soas.ac.uk/23855/

(18) Intom-x taraw il-postijiet fejn ghandhom jitwahћlu l-lampi? 2PL- $\check{\boldsymbol{s}}$ see.IMPF.2PL the-places where should.3PL attached.IMPF.3PL the-lamps 'Do you see the places where the lamps should be attached?' (Maltese; MLRS V.2.0 religion_Ih294)

(19) Xtaqt nistaqsi jekk [...] sibtu-x li kien hemm xi want.PRF.1SG ask.IMPF.1SG if find.PRF.2PL-̌̌ COMPbe.PRF.3MSG there any titjib jew jekk l-affarijiet baqghu-x kif kienu jew jekk improvement or if the-matters remain.PRF.3PL- ̌̌ how be.PRF.3PL or if marru-x lura.

go.PRF.3PL-̌̌ back

'I wanted to ask if you've found [...] that there has been any improvement or if matters have remained as they were or gone backwards.'

(Maltese; MLRS V.2.0 parl10202)

(20) Jekk trid-x żwieg minghajr skadenza isma' x'jghid-lek if want.IMPF.2SG- $\check{\boldsymbol{s}}$ marriage without deadline listen.IMP.SG what-say.IMPF.3MSG-to.2SG l-arcipriet $\mathrm{u}$ halli-k mill-hmerijiet. the-archpriest and keep.IMP.2SG-2SG from.the-nonsense 'If you want a marriage without a deadline, listen to what the archpriest tells you and keep away from mischief.'

(Maltese; MLRS V.2.0 press_orizzont64068)

As argued in LUCAS (2010), the neatest explanation for these facts is that šay'first grammaticalized as a generalizing adverb with a weak NPI-distribution, similar to English at all. In many dialects, such as Eastern Libyan (8)-(9) or Damascene (7), (16), the distribution of this adverb (realized as $\check{S} \check{l},-\check{S}^{\prime} i$, or $-\check{S}$ ) has narrowed just to polar questions. But in Maltese it seems to retain something like its original distribution, albeit it is far more frequent in embedded questions than in conditional or root interrogative clauses.

Regarding the question of exactly which item was reanalysed as the second element of a bipartite negative construction when this innovation first occurred in Arabic, there are, as noted in section 4, two obvious alternatives: either šay’in its original indefinite pronoun function ('anything') or the grammaticalized generalizing adverb šay'('at all') just discussed. The latter should probably be seen as the default hypothesis (it is the one argued for by DIEM 2014), but see LUCAS (2007: 418-22) for some arguments in favour of the former. A comparative illustration of Wilmsen's and the Jespersen-type reconstructions of these items is given in Figure 2.

\section{Conclusion}

For a variety of reasons, WILMSEN'S (2013a, 2014) alternative reconstruction of the development of negative $-s ̌$ in Arabic dialects cannot be sustained. Therefore the conventional reconstruction, according to which Arabic has undergone Jespersen's cycle, remains the most plausible account to date. It is important to note that the evidence against Wilmsen's reconstruction that we have reviewed here is at least as much Arabic-internal as it is comparative, despite Wilmsen's implication that the conventional reconstruction is led astray by superficial comparisons with the history of French. Nevertheless, in examining Wilmsen's proposals and his criticisms of the conventional reconstruction, we have had to confront an important but complex methodological problem for syntactic reconstruction in general: how to balance the need for unbiased appraisal of the relevant language-internal facts with the obvious requirement that reconstructions should be informed by an understanding of historical processes that are known to be crosslinguistically common. The answer that I have suggested here is that while linguistic facts internal to the reconstruction in question will always trump any external considerations, whenever we are faced with a choice between two or more reconstructions or analyses that cannot be resolved solely by internal linguistic data, the rational move is to favour the one that most resembles diachronic developments that are known to be common in the histories of other languages. 
This is the version of the article accepted for publication in Zeitschrift für arabische Linguistik published by Harrasowitz Verlag: https://www.jstor.org/journal/zeitarabling

Accepted version downloaded from SOAS Research Online: http://eprints.soas.ac.uk/23855/ 
This is the version of the article accepted for publication in Zeitschrift für arabische Linguistik published by Harrasowitz Verlag: https://www.jstor.org/journal/zeitarabling

Accepted version downloaded from SOAS Research Online: http://eprints.soas.ac.uk/23855/

\section{Wilmsen's reconstruction}

Proto-Semitic $s^{1}$ pronouns

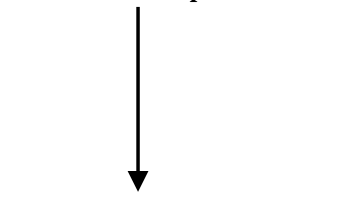

Interrogative $\check{s} i$

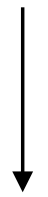

Negative $-\check{s}$
Lespersen-type reconstruction

šay"(any)thing'

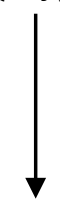

NPI adverb 'at all'

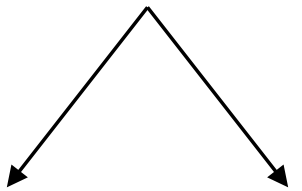

Negative $-\check{s}$
Interrogative $-\check{s}$

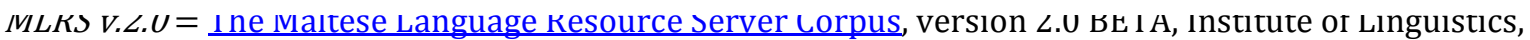
University of Malta

Quran $=\underline{\text { The Holy Quran }}$

\section{Works cited}

ABU HAIDAR, Farida. 1979. A study of the spoken Arabic of Baskinta. Leiden: Brill.

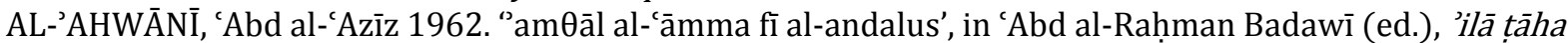
ḥusayn fi 'ìd mìlādihi as-sabiñn: dirāsāt muhdāt min 'aṣdiqāìhi wa talāmīđih (= Mélanges Taha Husain offerts par ses amis et ses disciples à l'occasion de son 70ième anniversaire), 235-367. Cario: Dār al-Ma'ārif.

AL-JALLAD, Ahmad. 2015. 'What's a caron between friends? A review article of Wilmsen (2014), with special focus on the etymology of modern Arabic šl, Bibliotheca Orientalis 72 (1-2), 34-46.

AMBROS, Arne. 1998. Bonġornu, kif int: Einführung in die maltesischen Sprache. Wiesbaden: Reichert.

BEHNSTEDT, Peter. 1985. Die nordjemenitischen Dialekte, Teil 1: Atlas. Wiesbaden: Reichert.

BEHNSTEDT, Peter. 1997. Sprachatlas von Syrien, vol. 1: Kartenband. Wiesbaden: Harrasowitz.

BEHNSTEDT, Peter \& Manfred Woidich. 2005. Arabische Dialektgeographie: Eine Einführung. (Leiden)

BERGMAN, Elizabeth M. 1996. 'ma-tir'af xeeri: Verbal negation in Egyptian and Moroccan Arabic proverbs', in Mushira Eid \& Dilworth Parkinson (eds.), Perspectives on Arabic Linguistics IX, 223-45. Amsterdam: Benjamins.

BORG, Alexander. 2004. A comparative glossary of Cypriot Maronite Arabic (Arabic-English). Leiden: Brill.

BRUSTAD, Kristen. 2000. The syntax of spoken Arabic: A comparative study of Moroccan, Egyptian, Syrian and Kuwaiti dialects. Washington DC: Georgetown University Press.

CAUBET, Dominique. 1993. L'arabe marocain. Paris: Peeters.

CLARK, Herbert. 1975. 'Bridging', in Roger C. Schank \& Bonnie L. Nash-Webber (eds.), Theoretical issues in natural language processing, 169-74. Cambridge, Mass.: Yale University Mathematical Social Sciences Board.

CORRIENTE, Federico. 1977. A Grammatical sketch of the Spanish Arabic dialect bundle. Madrid: Instituto Hispano-Árabe de Cultura.

COWELL, Mark W. 1964. A reference grammar of Syrian Arabic. Washington DC: Georgetown University Press.

DAHL, Östen. 1979. 'Typology of sentence negation', Linguistics 17, 79-106.

DAVIES, Humphrey Taman. 1981. 'Seventeenth-century Egyptian Arabic: A profile of the colloquial material in Yūsuf al-Širbīnī's Hazz al-Quhüüf fi Š̉arh Qasīd Abī Sādüf. PhD dissertation, University of California, Berkley.

DEUTSCHER, Guy. 2006. Review of RUBIN (2005).

DIEM, Werner. 2014. Negation in Arabic: A study in linguistic history. Wiesbaden: Harrasowitz. 
This is the version of the article accepted for publication in Zeitschrift für arabische Linguistik published by Harrasowitz Verlag: https://www.jstor.org/journal/zeitarabling

Accepted version downloaded from SOAS Research Online: http://eprints.soas.ac.uk/23855/

ESSEESY, Mohssen. 2009. 'Reanalysis', in Kees VERSTEEGH, Mushira EID, Manfred WOIDICH \& Andrzej ZABORSKI (eds.), Encyclopedia of Arabic language and linguistics, Volume IV, 37-43. Leiden: Brill.

ESSEESY, Mohssen. 2010. Grammaticalization of Arabic prepositions and subordinators: A corpus-based study. Leiden: Brill.

GARDINER, Alan H. 1904. 'The word iwn3’, Zeitschrift für Ägyptische Sprache und Altertumskunde 41, $130-5$.

HARRIS, Alice C. \& Lyle CAMPBELL. 1995. Historical syntax in cross-Linguistic perspective. Cambridge: Cambridge University Press.

HASPELMATH, Martin. 2007. 'Pre-established categories don't exist: consequences for language description and typology', Linguistic Typology 11:1, 119-32.

HEATH, Jeffrey. 2002. Jewish and Muslim dialects of Moroccan Arabic. London and New York: Routledge.

HEINE, Bernd. 2002. 'On the role of context in grammaticalization', in Ilse WISCHER \& Gabriele DIEWALD (eds.), New reflections on grammaticalization, 83-101. Amsterdam: Benjamins.

HERIN, Bruno. 2014. 'Salt, Dialect of', in Lutz EDZARD \& Rudolf DE JONG (eds.), Encyclopedia of Arabic language and linguistics online. Brill Online.

JASTROW, Otto. 2005. Glossar zu Kinderib (anatolisches Arabisch). Wiesbaden: Harrasowitz.

JESPERSEN, Otto. 1917. Negation in English and other languages (Historisk-filologiske Meddelelser 1). Copenhagen: A. F. Høst.

KHALAFALLAH, Abdelghany. 1969. A desriptive grammar of Saci:di colloquial Arabic. The Hague: Mouton.

KROCH, Anthony S. 1989. 'Reflexes of grammar in patterns of language change', Language Variation and Change 1, 199-244.

LUCAS, Christopher. 2007. 'Jespersen's Cycle in Arabic and Berber', Transactions of the Philological Society 105, 398-431.

LUCAS, Christopher. 2010. 'Negative -šin Palestinian (and Cairene) Arabic: Present and possible past', Brill's Annual of Afroasiatic Languages and Linguistics 2, 165-201.

LUCAS, Christopher. 2013. 'Negation in the history of Arabic and Afro-Asiatic', in Anne BREITBARTH, Christopher LUCAS \& David WILLIS (eds.), The development of negation in the languages of Europe and the Mediterranean, vol. 1, 399-452. Oxford: Oxford University Press.

LUCAS, Christopher \& Elliott LASH. 2010. 'Contact as catalyst: The case for Coptic influence in the development of Arabic negation', Journal of Linguistics 46(2), 379-413.

OBLER, Lorraine. 1990. 'Reflexes of Classical Arabic šay'un 'thing' in the modern dialects', in James BELLAMY (ed.), Studies in Near Eastern culture and history in memory of Ernest T. AbdelMassih, 132-52. Ann Arbor: University of Michigan.

OWENS, Jonathan. 1984. A short reference grammar of Eastern Libyan Arabic. Wiesbaden: Harrasowitz.

PALVA, Heikki. 2004. 'Negations in the dialect es-Salt, Jordan', in Martine HAAK, Rudolf DE JONG \& Kees VERSTEEGH (eds.), Approaches to Arabic dialects: A collection of articles presented to Manfred Woidich on the occasion of his sixtieth birthday, 221-36. Leiden: Brill.

PAT-EL, Na'ama. 2016. Review of Wilmsen (2014). Journal of Semitic Studies, 61(1), 292-295.

POLETTO, Cecilia. 2008. 'On negative doubling', Quaderni di Lavoro ASIt 8, 57-84. Available online at: http://asit.maldura.unipd.it/documenti/ql8/poletto 2008.pdf

REINHARDT, Carl. 1894. Ein arabischer Dialekt gesprochen in 'Oman und Zanzibar: Nach praktischen Gesichtspunkten für das Seminar für orientalische Sprachen in Berlin. Berlin: Spemann.

RUBIN, Aaron. 2005. Studies in Semitic grammaticaliztion. Winona Lake, Indiana: Eisenbrauns.

SEEGER, Ulrich. 1996. 'Der arabische Dialekt von il-Xalīl (Hebron)'. Magister dissertation, Universität Heidelberg.

SOUAG, Lameen. 2009. 'Siwa and its significance for Arabic dialectology', Zeitschrift für Arabische Linguistik 51, 51-75.

SOUAG, Lameen. 2016. 'Werner Diem: Negation in Arabic: A study in linguistic history', Linguistics 54(1), 223-229.

TIMBERLAKE, Alan. 1977. 'Reanalysis and actualization in syntactic change', in Charles N. LI (ed.), Mechanisms of syntactic change, 141-77. Austin: University of Texas Press.

TRUDGILL, Peter. 1974. 'Linguistic change and diffusion: Description and explanation in sociolinguistic dialect geography', Language in Society 3, 215-46.

VAN VALIN, Robert D. 2010. 'Role and reference grammar as a framework for linguistic analysis', in Bernd HEINE \& Heiko NARROG (eds.), The Oxford handbook of linguistic analysis, 703-38. 0xford: Oxford University Press.

WATSON, Janet C. E. 1993. A syntax of San'ani Arabic. Wiesbaden: Harassowitz. 
This is the version of the article accepted for publication in Zeitschrift für arabische Linguistik published by Harrasowitz Verlag: https://www.jstor.org/journal/zeitarabling

Accepted version downloaded from SOAS Research Online: http://eprints.soas.ac.uk/23855/

WILLIS, David. 2013. 'Brythonic Celtic', in David WILLIS, Christopher LUCAS \& Anne BREITBARTH (eds.), The history of negation in the languages of Europe and the Mediterranean, Volume I: Case studies, 239-98. Oxford: Oxford University Press.

WILLIS, David, Christopher LUCAS \& Anne BREITBARTH. 2013. 'Comparing diachronies of negation', in David WILLIS, Christopher LUCAS \& Anne BREITBARTH (eds.), The history of negation in the languages of Europe and the Mediterranean, Volume I: Case studies, 1-50. Oxford: Oxford University Press.

WILMSEN, David. 2013a. 'The interrogative origin of the Arabic negator -š: Evidence from copular interrogation in Andalusi Arabic, Maltese, and modern spoken Egyptian and Moroccan Arabic', Zeitschrift für Arabische Linguistik 58, 5-31.

WILMSEN, David. 2013b. Negation with post-positive $-\check{s}$ in Arabic dialects: An original feature not the end of a cycle. Paper presented at the 10th conference of the Association Internationale de Dialectologie Arabe, Doha, Qatar.

WILMSEN, David. 2014. Arabic indefinites, interrogatives and negators: A linguistic history of western dialects. Oxford: Oxford University Press.

WOIDICH, Manfred. 1968. 'Negation und negative Sätze im Ägyptisch-Arabischen'. PhD dissertation, Ludwig-Maximilians-Universität, Munich.

WOIDICH, Manfred. 2006. Das Kairenisch-Arabische: Eine Grammatik. Wiesbaden: Harrasowitz.

ZANUTTINI, Raffaella. 1997. Negation and clausal structure: A comparative study of Romance languages. New York: Oxford University Press. 